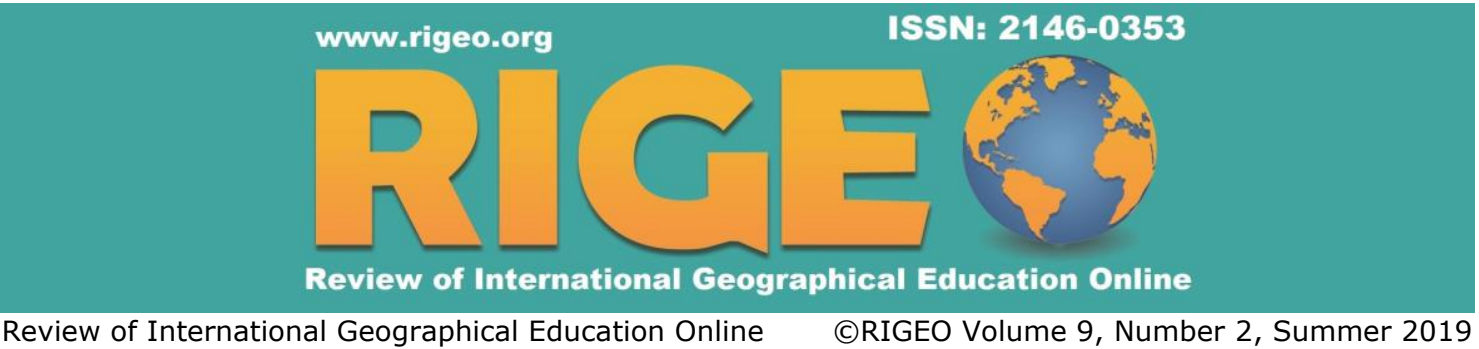

Research Article

Copyright @ RIGEO 2019

To cite this article: Trahorsch, P., Blaha, J. D, Chytrý, V. (2019). Comparative analysis of the quality of visuals in geography textbooks for ISCED 1 and ISCED 2 levels of education. Review of International Geographical Education Online (RIGEO), 9(2), 264-283. Retrieved from http://www.rigeo.org/vol9no2/Number2Summer/RIGEO-V9-N2-1.pdf

DOI: 10.33403 /rigeo.509255

Submitted: December 18, 2018

Revised: April 25, 2019

Accepted: June 4, 2019

\title{
Comparative Analysis of the Quality of Visuals in Geography Textbooks for ISCED 1 and ISCED 2 Levels of Education
}

\author{
Petr TRAHORSCH ${ }^{1}$ \\ J. E. Purkyně University in Ústí nad Labem, Ústí nad Labem, CZECHIA \\ Jan D. BLÁHA ${ }^{2}$ \\ J. E. Purkyně University in Ústí nad Labem, Ústí nad Labem, CZECHIA \\ Vlastimil CHYTRÝ ${ }^{3}$ \\ J. E. Purkyně University in Ústí nad Labem, Ústí nad Labem, CZECHIA
}

\begin{abstract}
The aim of the article is to assess the quality of visualisation of geomorphology, hydrology and agriculture of Czechia through maps, schemes and photographs in geography textbooks for ISCED 1 and ISCED 2 levels of education. A total of 15 geography textbooks were selected and a total of 90 visuals from these textbooks were analysed. The scaling method according to defined criteria relating to the concept of usability was applied; the result of scaling was the usability coefficient. The data obtained through scaling was subsequently statistically analysed. The outcomes of the statistical analysis show that the usability coefficient of visuals in textbooks for the older cohort is higher than in textbooks for younger students. The usability coefficient as an indicator of quality of the assessed visuals is linked especially to the tradition of publishing houses, as visuals in textbooks published by publishers with relatively long tradition are of a higher quality than those by publishers with shorter tradition and therefore less experience with publishing textbooks. Differences in the quality between individual types of visuals or themes are not statistically significant.
\end{abstract}

\section{Keywords}

Visual; Geography Textbook; Quantitative Content Analysis; Textbook Analysis; Geography Education.

\footnotetext{
${ }^{1}$ Corresponding author: Mgr. Petr Trahorsch, J. E. Purkyně University in Ústí nad Labem, Faculty of Education, Department of Preprimary and Primary Education, Hoření 13, Ústí nad Labem, Czechia, E-mail: petr.trahorsch [at] seznam.cz

${ }^{2}$ PhDr. RNDr. Jan D. Bláha, Ph.D., J. E. Purkyně University in Ústí nad Labem, Faculty of Science, Department of Geography, České mládeže 8, Ústí nad Labem, Czechia, E-mail: jd [at] jackdaniel.cz

${ }^{3} \mathrm{PhDr}$. Vlastimil Chytrý, PhD., J. E. Purkyně University in Ústí nad Labem, Faculty of Education, Department of Preprimary and Primary Education, Hoření 13, Ústí nad Labem, Czechia, E-mail: vlchytry [at] gmail.com
} 
The importance of visuals in modern geography textbooks is currently growing. Changes in the curriculum concept in certain countries and changed paradigms in geography are one of the causes of the growing importance of visuals (Zhang \& Foskett, 2003). As the scope and complexity of the curricula in most developed countries have grown over the last couple of decades, it can no longer be presented to students in the form of a text or lectures and spatially reduced and illustrative forms of communication need to be utilised (Lukinbeal, 2014; Spousta, 2007). Visuals describe, illustrate and concretise the content of textbooks (including the curriculum) and thus help in the learning process of difficult and abstract concepts (Peeck, 1993).

Visuals of (not only) geographic phenomena have a major potential for making the students' learning process more effective in the educational process (McTigue, 2009; Mayer, 2009). The advantage of visuals in textbooks (such as maps, charts, diagrams, photographs) when compared to other geographic didactic tools is in their relationship to other textbook components (such as explanatory texts, tasks, other types of visuals) (Behnke, 2017). Students can receive the curriculum content in various forms of external representation (Sternberg, 2012) and this allows for much more successful integration of the topics taught in the existing student's mental model compared to learning from text alone (Mayer, 2009). However, in certain cases visuals may be the source of students' misconceptions due to their inappropriate placement in the structure of textbooks or unsuitable means of expression (Dove, Everett \& Preece, 1999). An expert analysis (and the included assessment) of visuals may give authors of visuals and textbooks useful information about the quality of visualisation of geographical phenomena and thus supplement user assessment of visuals (e. g. Peterson, 2016).

In the past, the categorization of visuals according to various criteria was popular in geography textbooks research (Melbo \& Waterman, 1936; Wright, 1979). These criteria generally reflected the paradigms of geography and its field didactics. In recent years, an effort has been made to evaluate the hidden content of visuals and analyse them in terms of their learning potential (Slough, McTigue, Kim \& Jennings, 2010; Janko \& Knecht, 2013); methodological tools of expert research were gradually adjusted and standardized. Nevertheless, gaps in the state of knowledge in this area are still present. The current research of visuals in geography textbooks deals with the issue of absence of comprehensive expert assessment of the quality of visuals and this problem is closely connected to the non-existence of a fully standardised and available methodical assessment tool (compare for example Metallinos, Muffoletto, Petterson, Shaw \& Takakuwa, 1990, Tang, 1994; Yasar \& Seremet, 2007; Janko \& Knecht, 2013 etc.). Several synthetic research tools have been designed and verified (standardisation) for analyses examining the complexity or demands of explanatory texts (Mikk, 2000; pp. 199-242). The low numbers of analyses of visuals in geography textbooks may also be due to the subjectivity of assessment of visuals, which may lead to the analysis outcomes being affected by the assessor's error (Bláha, 2010). The application of certain procedures to make the assessment of visuals more objective is therefore desirable. This study therefore supplements the lacking knowledge of expert assessment of the quality of visuals. Furthermore, unlike studies already conducted (Janko \& 
Knecht, 2013; Tang, 1994 etc.), this study focuses on usability of visuals as one of the possible indicators of visualization quality (Hansen \& Gissel, 2018).

The primary aim of this study is to assess the quality of visualisation of selected geographical phenomena based on the outcomes of an expert quantitative content analysis of the selected visuals. This objective may identify errors in the concept of visuals in geography textbooks and thus provide a helpful feedback to the textbook (visuals) authors. The secondary objective is to compare visuals and their quality according to the evaluation criteria; this comparison will be based on the statistical analysis of the assessment outcomes.

\section{Visualisation of Geographical Phenomena in Geography Textbooks and Their Content Analysis}

Geography textbooks may be seen as a material didactic tool with a specifically structured system including elements in mutual interaction. The relationships and mutual connections between textbook components and elements allow students to use the textbooks effectively (usability concept - see below; Nielsen, 1994). According to academic publications focusing on the theory of textbooks and their structure, the text component, nonverbal (visual) component and the orientation apparatus may be defined (Wahla, 1983; Mikk, 2000).

Visuals can be described as depiction or illustration of the phenomena perceived by the human eye (Spousta, 2007). Visuals are part of the nonverbal component of textbooks, which is referred to in various ways across pedagogical, didactic and psychological research (compare Behnke, 2017; Janko \& Knecht, 2013; Veriki, 2002). The overview study analysis methodical approaches to the research of visuals in geography textbooks performed by Trahorsch, Bláha \& Janko (2018) identified a total of 20 special terms, ${ }^{3}$ all of which are more or less synonyms of the term visual; as these terms are highly general and are based on general theories of visualisation and communication (Veriki, 2002; Spousta, 2007), it will be used further in this study. The subjectivity and ambiguity of depiction or illustration of the visualised phenomenon is a typical characteristic of visuals, as different authors may choose various means of expression (such as colour, symbol shapes, etc.). The text (verbal) information is suppressed in visuals, which leads individuals to using the non-verbal reception channel and the visual cognitive processes (Sternberg, 2012). Owing to the use of the verbal (learning from text) and nonverbal (learning from visuals) channel for receiving information and the interaction between the individual channels, information from textbooks is stored in the students' memory twice (in the verbal and nonverbal form). A greater rigidity of change (remembering) is therefore ensured (Paivio, 2014).

3The overview study by Trahorsch, Bláha \& Janko (2018) analysed 92 research studies dealing with the visuals in geography textbooks. The results of this study were interpreted in terms of terminology, methodological approaches and synthesis of results. This overview study has shown that the following terms are used most frequently in studies focusing on textbook analysis: visual (Behnke, 2017), nonverbal mean (Fedotova, Latun \& Okuneva, 2014; Janko, 2012), graphical representation (Slough, McTigue, Kim \& Jennings, 2010), visual mean (Pešková, 2012), graphical display (Veriki, 2002) and visual element (Đukičin, Bibić, Lukić \& Dubovina, 2014). 
Geographic visuals, which may appear not only in modern geography textbook, but also in atlases, workbooks, digital textbooks and materials, etc. are a specific form of visuals. Their character stems from geography as a science studying primarily relationships and context in space and the interaction and relationships between nature and society. Geographic visuals allow visualisation of spatial differentiation of phenomena, display of characteristics of occurrences limited in space and have the potential to visualise hierarchical structure of phenomena and illustrate their relationships (Gregory, 2009).

Geographic visuals among other aspects develop the so-called visuospatial component of intelligence (graphicacy) in users and contribute to the development of spatial thinking and understanding of the basic geographical concepts in geography education (Jackson, 2006). Several studies especially in psychology or cognitive cartography based on the theory of multimedia learning (Mayer, 2009) or the conjunct theory (Verdi \& Kulhavy, 2002) document the impact of various characteristics of visuals of the effectiveness of students' learning (see further, Table 2). The characteristics of visuals influencing various levels of success in the learning process can be seen as the criteria useful for quantitative analysis of visuals (see for example Metallinos, Muffoletto, Petterson, Shaw \& Takakuwa, 1990; Tang, 1994; Yasar \& Seremet, 2007).

An expert analysis of geographic visuals belongs to the category of curriculum research, specifically to the group of textbook structure studies (Okeeffe, 2013). This type of study focuses on the analysis of latent content of visuals, which is often sidelined without adequate attention. We will therefore focus specifically on this form of analysis of visuals (Krippendorf, 2004; Trahorsch, Bláha \& Janko, 2018). The analysis of latent content of communication (visuals) focuses on its depth structure compared to the analysis of manifestation content; the evaluator analyses the visual properties that are not obvious at first sight (for example, the analysis of manifestation content will focus on the categorization of visual types, but the analysis of latent content will focus on scaling the degree of fulfilment of visual quality criteria). The analysis of latent content differs from the analysis of manifest content in a greater degree of subjectivity, which needs to be eliminated through suitable procedures. As this type of analysis is highly time consuming, it is necessary to use appropriately defined criteria to select those representative visuals that can be analysed using the scaling of various characteristics (criteria) of visuals.

One of the possibilities from which the theoretical framework can be used in defining the criteria for assessment of visuals in geography textbooks is the usability concept (Hansen \& Gissel, 2018). Usability is defined as a quality attribute that evaluates the ease of use for the users; according to Nielsen (1994), usability has 6 basic components: learnability efficiency, memorability, errors, satisfaction, and utility. The criteria have to be based on previously research (Bláha, 2010; Trahorsch, Bláha \& Janko, 2018). 


\section{Methodology}

\section{Research Design}

In this study, the authors use a quantitative expert analysis of latent content of visuals in geography textbooks. This approach allows assessing the quality of visualisation of selected geographical phenomena, as it focuses on an in-depth analysis of visuals (Krippendorf, 2004). The numerical expression of the analysis results allows comparing the quality (usability) of visuals according to various comparative criteria (for example according to the type of visuals, topic of visuals, individual publishing houses, etc.).

\section{Study Group}

A total of 15 Czech-regional geography textbooks for the ISCED 1 (textbooks for 10-year-old students) and ISCED 2 (textbooks for 14-year-old students) levels of education were selected because both of these groups have a comparable content (regional geography curriculum relating to Czechia). Only printed textbooks published after 2007 (the requirement of currency) were assessed, as they are used in Czech schools more frequently than digital textbooks. All selected textbooks had the clause of the Ministry of Education, Youth and Sports, which functions in Czechia as a guarantee of the specialised didactic quality of the didactic tool. An overview of the assessed textbooks is provided in Table 1.

A total of 60 visuals in textbooks for ISCED 1 and a total of 30 visuals in textbooks for ISCED 2 were assessed. As the researchers aimed to assess visuals with as many identical characteristics as possible, the following criteria for selecting the assessed visuals were defined:

- the type of the assessed visual will be a map, diagram, photograph ${ }^{4}$

- the assessed visual relates to three areas of study, specifically geomorphology, hydrology, agriculture because these topics are very frequent in the evaluated geography textbooks being reviewed and include topics of both physical and social geography;

- the visual states the topic: map of the surface of Czechia, photograph of mountain Snežka, diagram of altitudes; water map of Czechia, photograph of confluence, diagram of watercourse flow; map of agriculture in Czechia, photograph of hops growing, diagram of chernozem.

Visuals meeting all specified criteria were selected from each of the textbooks. Where visuals from a specific area of study or a specific topic were not present in a textbook, the number of the assessed visuals from the relevant textbook is logically lower (see Table 1).

${ }^{4}$ As there are very few graphs published in textbooks for ISCED 1, the authors did not include any graphs in the analysis. 
Table 1

Overview of analysed geography textbooks

\begin{tabular}{|c|c|c|c|}
\hline Quotation & $\begin{array}{l}\text { Level of } \\
\text { education }\end{array}$ & Publishing house & $\begin{array}{c}\text { Textbook scope } \\
\text { (number of visuals } \\
\text { assessed) }\end{array}$ \\
\hline $\begin{array}{l}\text { Čechurová, Ježková \& Borecký } \\
\text { (2016) }\end{array}$ & ISCED 1 & SPN & 113 pp. (8) \\
\hline Štiková \& Tabárková (2016) & ISCED 1 & Nová škola & 64 pp. (7) \\
\hline Matušková \& Šmolíková (2010) & ISCED 1 & Septima & 52 pp. (6) \\
\hline Hroudová \& Cimala (2013) & ISCED 1 & Nová škola - Duha & 60 pp. (8) \\
\hline Smolová \& Szczyba (2008) & ISCED 1 & Prodos & 96 pp. (4) \\
\hline Mandelová (2007) & ISCED 1 & Dialog & 112 pp. (3) \\
\hline $\begin{array}{l}\text { Viceníková, Sakařová \& Kamrla } \\
\text { (2016) }\end{array}$ & ISCED 1 & Taktik & 64 pp. (8) \\
\hline Hublová (2009) & ISCED 1 & Didaktis & 95 pp. (6) \\
\hline Matušková (2010) & ISCED 1 & Nakladatelství ČGS & 88 pp. (5) \\
\hline Chalupa (2010) & ISCED 1 & Alter & 44 pp. (4) \\
\hline $\begin{array}{l}\text { Borecký, Novák \& Chalupa } \\
\text { (2013) }\end{array}$ & ISCED 2 & Nová škola - Duha & 96 pp. (7) \\
\hline Voženílek \& Szczyba (2015) & ISCED 2 & Prodos & 112 pp. (7) \\
\hline $\begin{array}{l}\text { Chalupa, Horník \& Demek } \\
\text { (2015) }\end{array}$ & ISCED 2 & SPN & 112 pp. (5) \\
\hline $\begin{array}{l}\text { Marada, Havlíček, Matějček, } \\
\text { Hanus \& Chromý (2016) }\end{array}$ & ISCED 2 & Fraus & 136 pp. (5) \\
\hline $\begin{array}{l}\text { Kastner, Holeček \& Krajíček } \\
(2016)\end{array}$ & ISCED 2 & Nakladatelství ČGS & 104 pp. (5) \\
\hline
\end{tabular}

\section{Data Collection}

The presented methodical tool is based on the concept of usability, which takes into account the effectiveness of the learning process and the ease of using a specific product (Nielsen, 1994). The methodical progress of assessment can be described as deductively inductive. The analysis of visuals in textbooks was carried out in two stages.

The first stage of the analysis involved collection of quantitative nominal and ordinal data relating to the general details about the textbooks (such as the author, year of publishing, scope, etc. - see Table 1) and the publishing houses (tradition, year of establishing, position on the Czech market, etc.).

The second stage of the analysis involved assessment of specific visuals selected according to the defined selection criteria. Assessment criteria are based on visual characteristics that influence learning effectiveness (see above). Determination of the assessment criteria is to some extent subjective in each study, therefore the authors of this study tried to base their definition on empirical research in pedagogical and cognitive psychology and user surveys in cartography. ${ }^{5}$ The established assessment

${ }^{5}$ The empirical studies had to be published in a periodical included in the SCOPUS or Web of Science databases. 
criteria are also based on the research already carried out (e.g. Tang, 1994; Mikk, 2000, pp. 269-309; Yasar \& Seremet, 2007). Selected visuals were assessed using the scaling method based on predefined assessment criteria. These criteria document varying effectiveness of students' learning and problem solving and show the educational potential of visuals. The authors of this study defined two groups of criteria (see Table 2 ). The first group related to general integration of a specific visual in the textbook, while the second group concerned individual characteristics of the visual. The scales expressing the level of fulfilment of the defined assessment criteria were from 1 to 5 or from 1 to 3, value 1 being awarded for the lowest rate of fulfilment and value 5 (or 3) being awarded for the highest rate of fulfilment of the relevant criteria by the assessed visual.

Table 2

Overview of assessment criteria including their definition and reference to an expert study

\begin{tabular}{|c|c|c|}
\hline $\begin{array}{l}\text { Name of } \\
\text { assessment } \\
\text { criterion }\end{array}$ & $\begin{array}{l}\text { Example of } \\
\text { empirical study }\end{array}$ & Examples of assessed visual characteristics \\
\hline $\begin{array}{l}\text { Position on the } \\
\text { page }\end{array}$ & Peterson (2016) & $\begin{array}{l}\text { Suitability of page composition with regard to the } \\
\text { visual (size, placement, etc.). }\end{array}$ \\
\hline $\begin{array}{l}\text { Relationship to the } \\
\text { text }\end{array}$ & $\begin{array}{l}\text { Kim, Lim \& } \\
\text { Yang (2016) }\end{array}$ & $\begin{array}{l}\text { Relationship between the text content and the } \\
\text { visual (matching content, references, reading } \\
\text { instructions, distance of visual from the text). }\end{array}$ \\
\hline Title & $\begin{array}{c}\text { Mayer \& } \\
\text { Gallini (1990) }\end{array}$ & $\begin{array}{c}\text { Presence and characteristics of title (relevancy, } \\
\text { aptness, placement). }\end{array}$ \\
\hline Attractiveness & $\begin{array}{c}\text { Bresciani \& } \\
\text { Eppler (2015) }\end{array}$ & $\begin{array}{l}\text { Level of attraction by quality, innovation and } \\
\text { novelty of the visual. }\end{array}$ \\
\hline Aesthetic function & Hollman (2014) & $\begin{array}{l}\text { Willingness to work with the visual, relationship } \\
\text { to the aesthetic sense of the user. }\end{array}$ \\
\hline Adequacy & $\begin{array}{l}\text { Michaelidou, } \\
\text { Nakos \& } \\
\text { Filippakopoulou } \\
\text { (2004) } \\
\end{array}$ & $\begin{array}{l}\text { The appropriateness of the visual in relation to the } \\
\text { cognitive assumptions of the user curriculum. }\end{array}$ \\
\hline Clarity & $\begin{array}{c}\text { Ozcelik, } \\
\text { Karakus, } \\
\text { Kursun \& } \\
\text { Cagiltay (2009) }\end{array}$ & $\begin{array}{l}\text { Generating a clear idea of the presented } \\
\text { phenomenon based on the use of the visual } \\
\text { (suitability of use or unambiguous interpretation } \\
\text { of the means of expression). }\end{array}$ \\
\hline Distinctiveness & $\begin{array}{l}\text { Cromley, Perez, } \\
\text { Fitzhugh, } \\
\text { Newcombe, } \\
\text { Wills \& Tanaka } \\
\text { (2013) }\end{array}$ & $\begin{array}{c}\text { Distinctiveness and ease of interpretation of } \\
\text { various means of expression (colour, shapes, } \\
\text { sizes). }\end{array}$ \\
\hline Clear arrangement & Behnke (2017) & $\begin{array}{c}\text { Speed of orientation in the visual influenced } \\
\text { especially by depicting the hierarchy of the } \\
\text { phenomena, links, options for comparing } \\
\text { phenomena. }\end{array}$ \\
\hline
\end{tabular}




$\begin{array}{lcc}\text { Legibility } & \begin{array}{c}\text { Canham \& } \\ \text { Hegarty (2010) } \\ \text { Binsworth }\end{array} & \begin{array}{c}\text { Ease of reading information from the visual } \\ \text { influenced especially by the choice of colour. } \\ \text { Overall and local filling of the visual space with } \\ \text { information (for example crowded versus empty), } \\ \text { distractive elements in the visual. } \\ \text { (2006) }\end{array} \\ \text { Expertise } & \text { Butcher (2006) } & \begin{array}{c}\text { Relationship to terminological and specialised } \\ \text { rules and scientific knowledge, quality of } \\ \text { processing. }\end{array}\end{array}$

As an analysis of visuals by a single assessor may be affected by errors in assessment, the importance (weight) of individual criteria was determined. A total of 18 academics was involved in the specification of the importance of the assessment criteria (12 geographers and 6 pedagogues) from the J. E. Purkyně University in Ústí nad Labem. The respondents are experts in didactics and the geography education and regularly publish research articles over the last three years. The respondents received a questionnaire, where they expressed their opinion on the importance of one of a pair of criteria using the pair comparison method. The outcomes are provided in Table 3 . The number of options (o) refers to the number of choices of experts for each of the criteria; the weighting coefficient $(\mathrm{w})$ was calculated according to the following formula:

$$
w=\frac{1}{\frac{\sum_{i=1}^{n}}{o_{i}}},
$$

where $o_{i}$ is the number of selections for each i-th criterion in the group, $n$ is the number of assessment criterions in each group $(n=6)$.

Table 3

Results of pair comparison by experts

\begin{tabular}{ccc}
\hline Assessment criterion & Number of options (o) & Weighting coefficient (w) \\
\hline Position on the page & 26 & .0959 \\
Relationship to the text & 68 & .2509 \\
Title & 32 & .1181 \\
Attractiveness & 40 & .1476 \\
Aesthetic function & 27 & .0996 \\
Adequacy & 78 & .2878 \\
\hline Clarity & 58 & .2140 \\
Distinctiveness & 28 & .1033 \\
Clear arrangement & 65 & .2399 \\
Legibility & 55 & .2030 \\
Balance & 21 & .0775 \\
Expertise & 44 & .1624
\end{tabular}


Converting the scaling results to a uniform assessment scale while taking into account the weight (importance) of the criteria was necessary for the statistical analysis of the outcomes of the second stage. This conversion was carried out according to the following formula:

$$
u c_{i}^{c}=n \times k_{i}^{u} \times w_{i}^{c},
$$

$u c_{i}^{c}=$ usability coefficient of each i-th visual, $n=$ total number of criteria (in group), $k_{i}^{u}=$ rate of fulfillment of each i-th criterion without taking account of weights (weighting coefficient), $w_{i}^{c}=$ the total weighting coefficient of each i-th criterion.

\section{Data Analysis}

The rate of fulfilment of six general and six specific assessment criterions taking into account the importance of these criterions was used to calculate the median, as the data have the character of an ordinal scale (Chytrý \& Kroufek, 2017). The overall outcome for the quality of the visual in terms of its usability is expressed by the so-called usability coefficient with values in the range uc $=\langle 0 ; 100\rangle$; value 100 expresses the maximum level of fulfilment of the usability criterion and therefore the best available option (we assess quality through usability assessment). The numerical values according to the individual comparative criteria (such as the age of the visual users, visual type, area of study, individual criteria) stated further in the text are the median of all usability coefficients of visuals in the relevant category. Depending on the number of groups, the outcomes were analysed by the Mann-Whitney test or the Kruskal-Wallis test on the significance level of $\alpha=.05$. Mann-Whitney test is used for ordinal data (or for data with no normal frequency distribution); it detects the difference of medians between two tested groups. Kruskal-Wallis test is also used for ordinal data, but unlike the MannWhitney test, it detects the difference of medians between more than two groups.

Before the visuals in geography textbooks were analysed, the research instrument was presented to three experts from the field (geography education), who provided their statement regarding its validity (triangulation - Cohen, 2007). The methodical tool was modified according to their comments. The pair comparison method, which introduces the view of additional experts to the obtained results, was used to eliminate subjectivity. Furthermore, pilot testing of the research instrument was carried out. Selected visuals were assessed by three experts who provided subsequent consultation during the pilot testing. This process helped to clarify the characteristics of visuals assessed under the individual assessment criteria and helped eliminate the subjectivity of one evaluator when evaluating visuals. The definition of certain assessment criteria was modified slightly after the pilot testing.

\section{Findings}

The results of scaling show that the assessed visuals in textbooks for the older age group ( $u c_{I S C E D 2}=73.51$ ) reach a higher level of quality compared to the textbooks for the ISCED 1 category $\left(u c_{I S C E D 1}=70.85\right)$. The Mann-Whitney (1947) test has shown a statistically significant difference between the two age groups $(U=668.5, p=.048)$. 
The position of visuals within the textbook structure is the probable cause of this difference; visuals in textbooks for younger students have mainly decorative and motivational purpose and this may deteriorate the fulfilment of the criteria of integration of the visual in the textbook structure. Furthermore, visuals for younger students tend to use unsuitable means of expression (such as selection of colours, symbols, etc.) in abstract visuals.

The Kruskal-Wallis (1952) test has shown that the differences between the assessed maps, diagrams and photographs are not statistically significant; $\mathrm{H}(2, \mathrm{~N}=90)=1.08, p$ $=0.58$. Nonetheless, small differences may still be identified through closer analysis of the outcomes of scaling in a box plots diagram (see Figure 1). Maps reached relatively lower usability rates than diagrams and photographs. This is probably due to the most complex process of creating maps and a range of cartographic rules, which are not observed especially in maps in textbooks for the younger age group (such as the absence of the scale, incomplete key, unsuitable selection of cartographic depiction, etc. - see Figure 2).

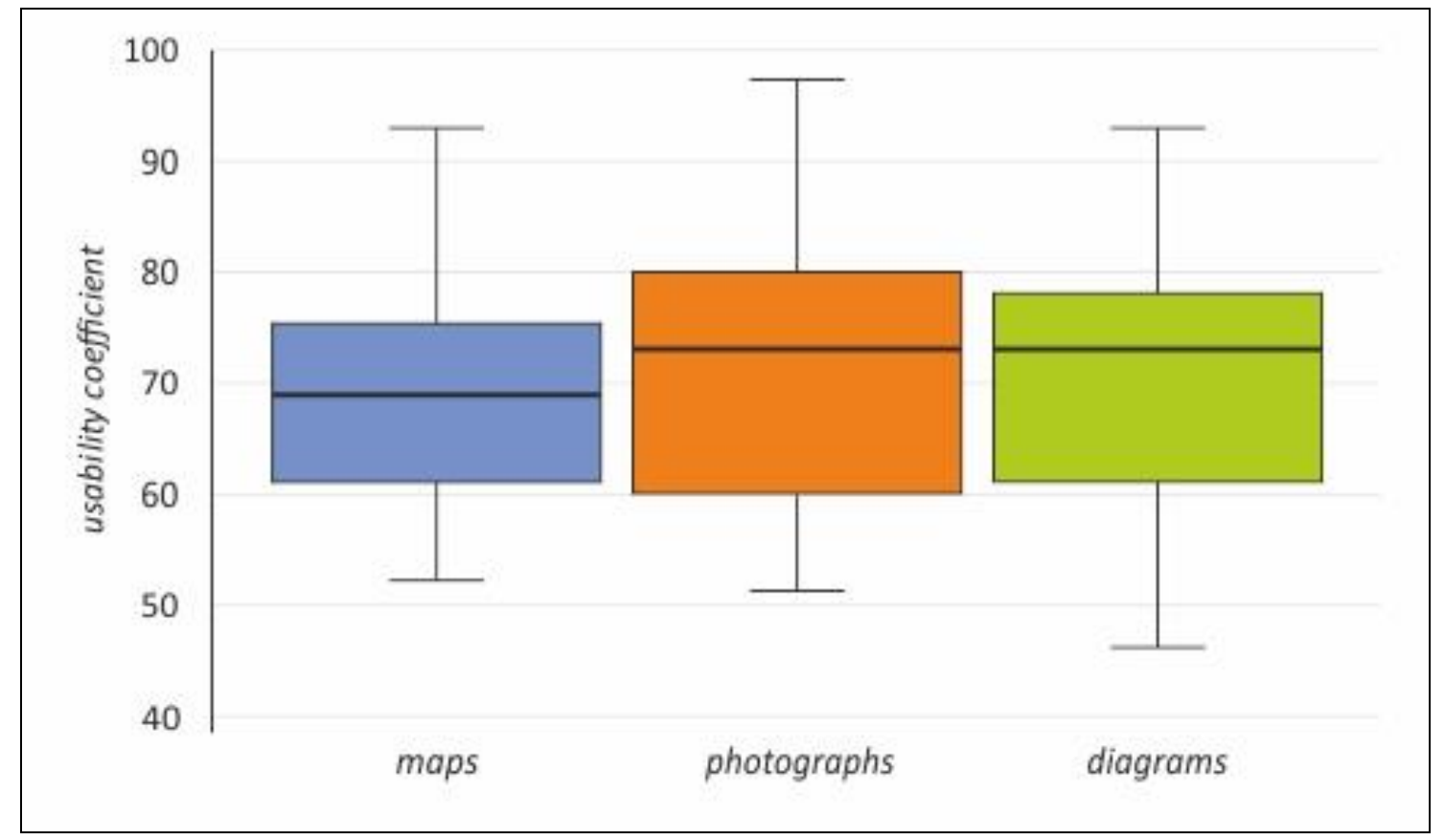

Figure 1. Usability coefficient in individual types of visuals 


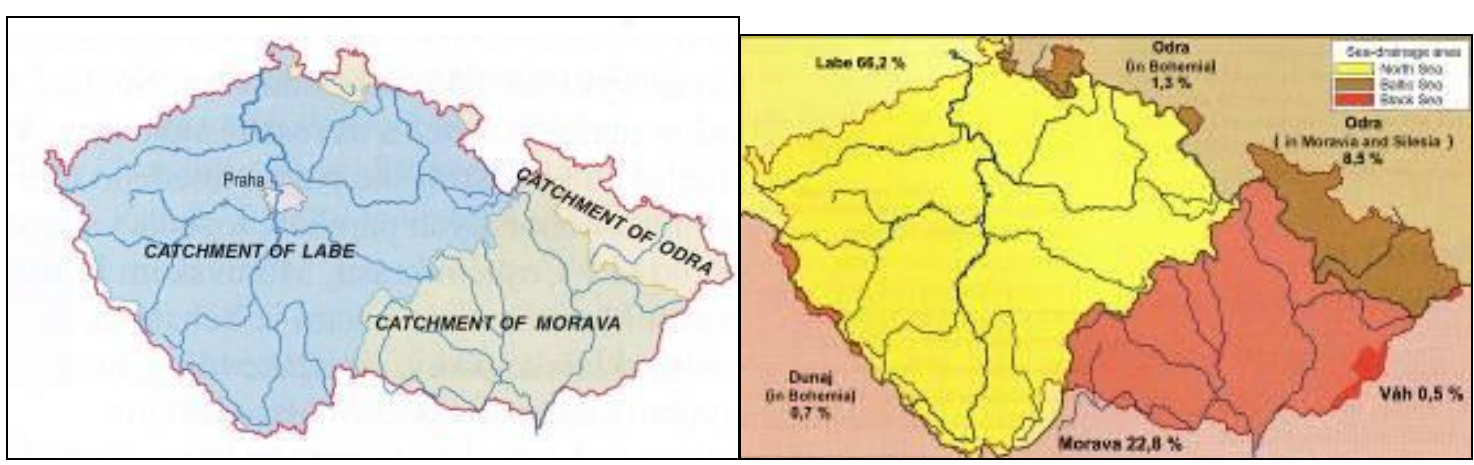

Figure 2. Example of the lowest quality (on the left) and the highest quality (on the right) map of water bodies in Czechia (absence of the basic composition elements, absence of a title)

The comparison of the quality of individual types of visuals between the textbooks for the younger and older cohort has produced some interesting results (Table 4). Schemes in textbooks for the older age group have higher quality due to a more suitable selection of means of expression (colours, shapes, size of symbols) and their integration in the textbook (size, relationship to the text, etc.); finally, certain specialised (terminological) errors in diagrams in textbooks for the younger age group, which may lead to students' misconceptions, contribute to this difference (compare Figure 3). The quality of photographs in both monitored age groups does not differ; photographs as realistic visuals (Rose, 2008) do not place practically any demands on their creation using information technologies. Photographs eliminate the subjectivity of their author and this logically lowers the differences in the level of usability compared to the relatively more subjective selection of means of expression in maps and diagrams.

Table 4

Usability coefficient by visual type

\section{Textbooks for ISCED Textbooks for ISCED}

\begin{tabular}{ccc} 
& $\mathbf{1}$ & $\mathbf{2}$ \\
\hline Maps & 64.65 & 71.73 \\
Photographs & 73.06 & 73.06 \\
Diagrams & 67.03 & 74.39 \\
\hline
\end{tabular}




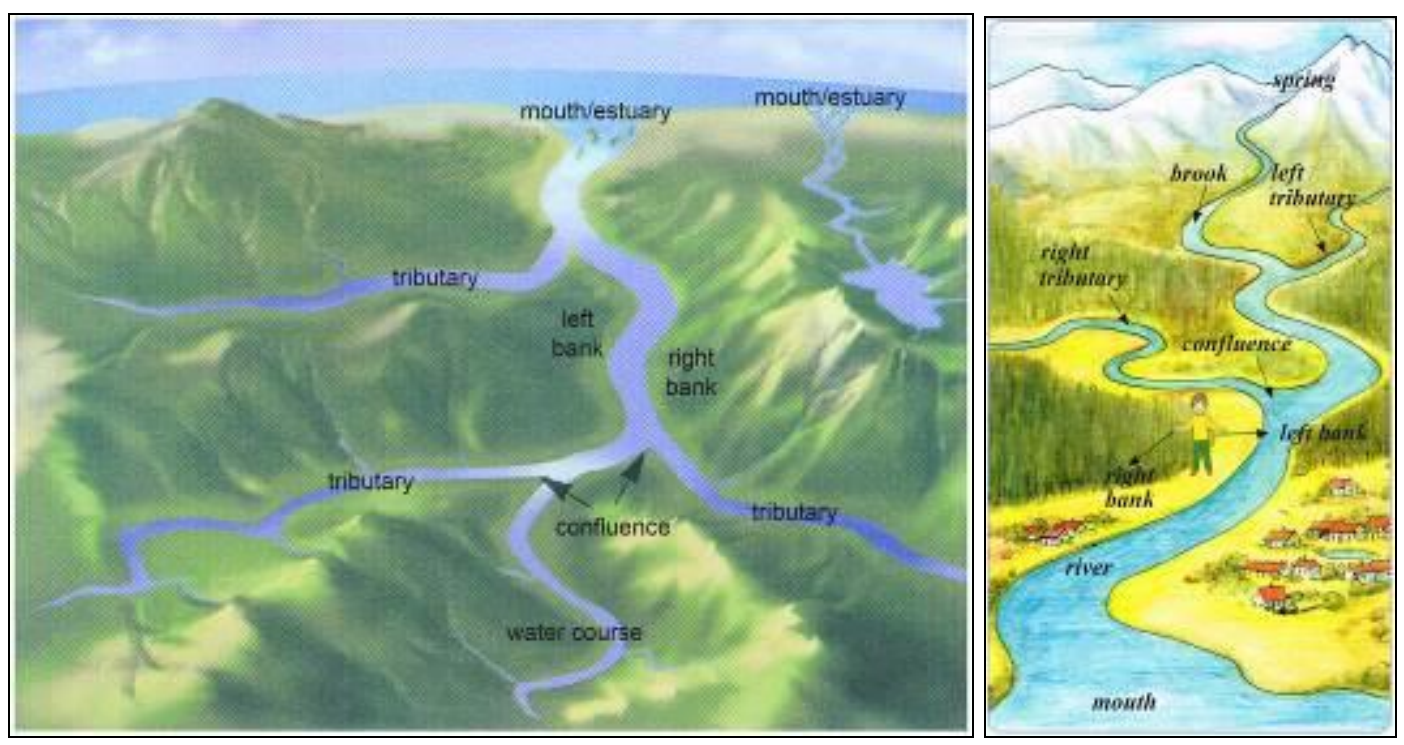

Figure 3. Example of the lowest quality (on the left) and the highest quality (on the right) diagram of watercourse flow (unsuitable orientation, errors in description, unsuitable use of colours)

The Kruskal-Wallis test has shown that there is no difference between the quality of visualisation of the three monitored areas of study (geomorphology, hydrology, agriculture) in general or in both age groups separately (see Table 5$) ; \mathrm{H}=(2, \mathrm{~N}=90)$ $1.28, p=0.53$. As the authors of textbooks pay attention to consistent design of visuals, their quality does not differ significantly between individual topics (see Figure 4). The use of conventions in visuals (such as the convention regarding visualisation of watercourses on maps, the convention for visualisation of altitude using the colour hypsometry method, arrows in diagrams to illustrate dynamics, etc.) also contributes to this outcome.

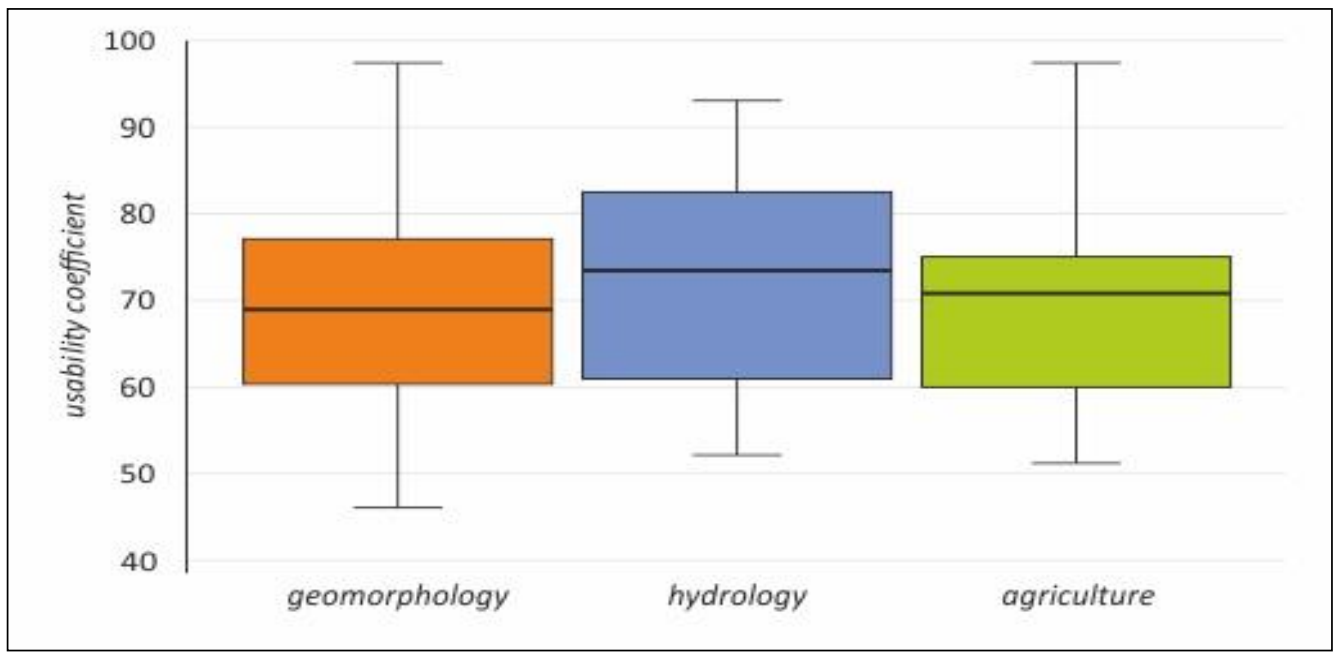

Figure 4. Usability coefficient in individual types of individual topics 
Table 5

Usability coefficient by topic

\begin{tabular}{ccc}
\hline & Textbooks for ISCED & Textbooks for ISCED \\
& $\mathbf{1}$ & $\mathbf{2}$ \\
\hline Geomorphology & 70.85 & 73.73 \\
Hydrology & 73.06 & 79.32 \\
Agriculture & 70.85 & 73.06 \\
\hline
\end{tabular}

The main differences in the level of fulfilment of individual assessment criteria may be identified based on the statistical analysis of the individual criteria (see Table 6). Significant differences in the level of fulfilment of individual criteria between the age groups were identified in the attractiveness criteria $(U=686 ; p=.049)$ and aesthetic function $(\mathrm{U}=569,6 ; p=.003)$. These criteria reach higher values in textbooks for ISCED 2. However, it is necessary to add that the authors of visuals should consider more some of the criteria (characteristics of visuals) with regard to the age of the users; this applies especially to the level of expertise, which should be higher with the increasing age of the students because the students already have developed cognitive skills for understanding abstract concepts, as well as specialised terminology in the scientific discipline; younger students thus face relatively high requirements for understanding abstract concepts from the visual (see e.g. Figure 5). The statistical analysis has furthermore documented the impact on the type of a visual on the level of fulfilment of the individual assessment criteria on the position on the page $(p=.001)$, relationship of the visual to the text $(p=.020)$, level of distinctiveness $(p=.022)$ and expertise $(p=.041)$. This result is probably caused by the different character of means of expression in the monitored types of visuals and by the various functions of visuals in the textbooks; for example, the representative or organising function prevails in maps, while photograph follow mainly the decorative purpose (Levin, Anglin \& Carney, 1987). This influences the position of the visual on the page and relationship to the text (references, matching content, filling empty spaces). The topic of visualisation only influences the assessment of the adequacy assessment criterion $(p=.049)$.

Table 6

Rate of fulfilment of each of assessment criteria without taking account of weights

\begin{tabular}{ccccccccc}
\hline Criterion & \multicolumn{2}{c}{ Age group } & \multicolumn{3}{c}{ Visual type } & \multicolumn{3}{c}{ Topic of visualisation } \\
\hline Category & $\begin{array}{c}\text { ISCED } \\
1\end{array}$ & $\begin{array}{c}\text { ISCED } \\
2\end{array}$ & map & $\begin{array}{c}\text { photo- } \\
\text { graph }\end{array}$ & diagram & $\begin{array}{c}\text { geomor- } \\
\text { phology }\end{array}$ & $\begin{array}{c}\text { hydrolo- } \\
\text { gy }\end{array}$ & $\begin{array}{c}\text { agricul- } \\
\text { ture }\end{array}$ \\
\hline $\begin{array}{c}\text { Position } \\
\text { on the } \\
\text { page }\end{array}$ & 80 & 75 & 80 & 70 & 80 & 70 & 90 & 70 \\
$\begin{array}{c}\text { Relationsh } \\
\text { ip to the } \\
\text { text }\end{array}$ & 70 & 60 & 70 & 60 & 70 & 60 & 70 & 60 \\
$\begin{array}{c}\text { Title } \\
\text { Attractive } \\
\text { ness, }\end{array}$ & 85 & 70 & 90 & 90 & 80 & 80 & 80 & 80 \\
& 60 & 80 & 60 & 60 & 60 & 60 & 80 & 70 \\
\hline
\end{tabular}




\begin{tabular}{|c|c|c|c|c|c|c|c|c|}
\hline $\begin{array}{l}\text { innovation } \\
\text { Aesthetic } \\
\text { function }\end{array}$ & 90 & 100 & 100 & 90 & 90 & 100 & 90 & 90 \\
\hline Adequacy & 80 & 90 & 80 & 90 & 100 & 80 & 100 & 80 \\
\hline Clarity & 60 & 80 & 80 & 60 & 80 & 60 & 80 & 80 \\
\hline $\begin{array}{l}\text { Distinctiv } \\
\text { eness }\end{array}$ & 60 & 80 & 80 & $x$ & 60 & 70 & 70 & 80 \\
\hline $\begin{array}{c}\text { Clear } \\
\text { arrangeme } \\
\text { nt }\end{array}$ & 70 & 80 & 80 & 75 & 70 & 70 & 80 & 80 \\
\hline Legibility & 70 & 80 & 70 & 80 & 80 & 80 & 80 & 80 \\
\hline Balance & 100 & 100 & 100 & 100 & 100 & 100 & 100 & 100 \\
\hline Expertise & 80 & 80 & 60 & 85 & 80 & 80 & 80 & 80 \\
\hline
\end{tabular}

Note: the numerical values in the table indicate the fulfilment of the evaluation criterion by individual categories of analysis (e.g. two age groups, three visual types, etc.) without taking into account importance; the values are converted to a uniform assessment scale $<0 ; 100\rangle$.

The comparison of the quality of the analysed visualisation between individual publishing houses using the Kruskal-Wallis test has shown that statistically significant differences exist in the quality of visuals (i.e. in the level of fulfilment of individual criteria); $\mathrm{H}=(9, \mathrm{~N}=1032) 22.40, p=.008$. Analysed visuals from publishing houses with relatively long tradition of publishing textbooks have the highest quality; conversely, the lowest quality of visuals is found in textbooks by publishing houses with little experience in producing textbooks and poorer establishment on the Czech market with textbooks (see Figure 5). The lower level of the author's knowledge or insufficient skills of the graphic artist, who is often responsible for creating visuals, may contribute to these differences (Benson, 1997).

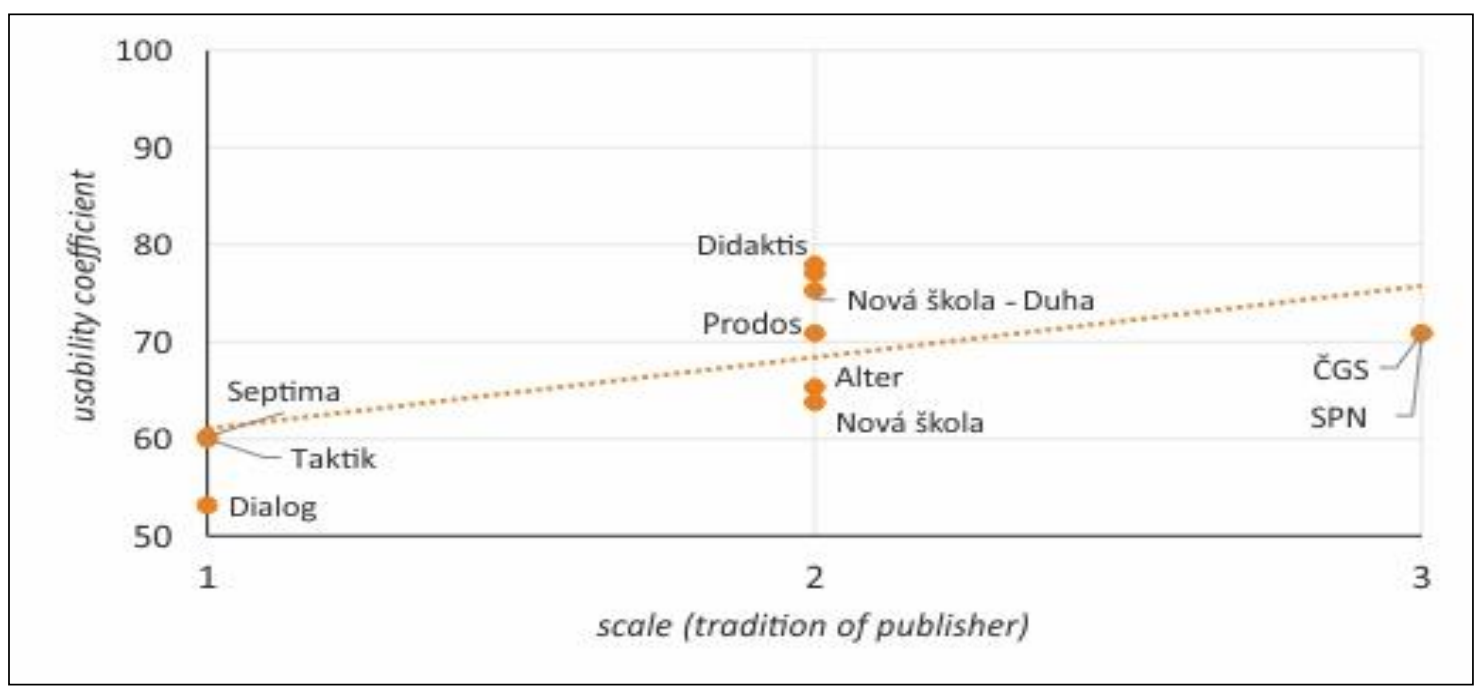

Figure 5. Usability coefficient in individual publishing houses depending on their tradition with a linear trend connection 


\section{Discussion}

The presented results show that there are only small differences in the quality of visualisation of geographical phenomena according to the individual criteria (type of visual, area of study, etc.). This result is especially due to the selection of the research sample. Exclusively textbooks with a clause of the Czech Ministry of Education, Youth and Sports were selected; before a textbook is awarded this clause, it is subjected to several expert reviews and this may affect the quality of visuals in the textbooks. If textbooks without the specified clause were also selected, the quality of visuals would probably be rather varied. Furthermore, experts from the relevant fields participate in the creation of these textbooks and these may guarantee the specialised didactic quality (correctness) of visuals.

The results of this study point to a relatively weak relationship between visuals and the explanatory text in the textbooks. This problem may reduce the effectiveness of students' learning significantly (for example Behnke, 2017; Mayer \& Gallini, 1990; Kim, Lim \& Yang, 2016). Metallinos, Muffoletto, Petterson, Shaw \& Takakuwa (1990) also point out the inadequate relationship between text and visuals in certain types of textbooks.

The relatively major variability in the quality of visual titles may also be seen as problematic. A title is one of the elements of a visual that attracts the user's attention to the visual (McTigue \& Flowers, 2011). A study by Slough, McTigue, Kim \& Jennings (2010) also found the absence of titles in large numbers of visuals in textbooks (18.5\%). Tang (1994) furthermore proved in his study assessing visuals by the scaling method that titles in Canadian geography textbooks lack aptness. However, the character of titles is rather varied compared to this study, depending mainly on the publishing house. It is the publishing house that strives to maintain a consistent style (character) of titles throughout the textbook.

The low level of fulfilment of the attractiveness and innovation criterion is rather surprising. This result is associated with frequent copying of the concept of visuals across textbooks. The authors of textbooks do not strive to innovate visuals. A certain form of seriality, i.e. repeating the established and familiar, is practically the consequence of lower creativity of the authors (Bláha 2006). Dove, Everett \& Preece (1999) have found that this phenomenon has a major impact on the student's mental model, which can lead to students' misconceptions.

A older research by the authors Melba \& Waterman (1936) has shown that the level of fulfilment of the readability and attractiveness criterion in visuals in American geography textbooks was low, which is probably due to the poorer technical specification of printing and reduced options in creating and editing maps and diagrams compared to the present times (the use of information technologies, better quality of printing, etc.).

Yasar \& Seremet (2007) document on the basis of the outcomes of scaling photographs in Turkish geography textbooks that visualisation of the assessed physical 
and geographical phenomenon (earthquake) is higher than the quality of visualisation of the socio-economic phenomenon (foreign trade). The cause is seen in the fact that physical and geographical visuals focus on higher cognitive functions according to the Bloom's taxonomy, which means that these visuals can facilitate learning more and contribute to students' problem solving. On the other hand, visualisation of a sociogeographical phenomenon is more of a descriptive character. Conversely, the results of this study suggest that the quality of visualisation of geomorphological phenomena is problematic due to a low level of expertise (terminological errors) and unsuitable selection of means of expression in maps and diagrams. It is necessary to point out that the quoted authors mainly assessed photographs, where the requirements for the overall concept of the visual are lower.

\section{Conclusions}

The assessment of the quality of textbooks and the visuals contained in them has a potential of becoming a tool for improving the quality of visualisation of geographical phenomena. While quantitative assessment of visuals cannot identify specific defects in visuals that would reduce the effectiveness of learning, the presented methodology can be used to identify general defects in visualisation of geographical phenomena according to the selected comparative criteria (such as the age group, type of visuals, etc.). One of the advantages of the presented methodology lies in the option of comparing the outcomes of this study with similar researches in various periods or focusing on different types of textbooks.

On the other hand, this study may be limited by the relatively subjective specification of the criteria for the latent content of visuals (it is possible that other experts would select different criteria). However, the authors of this study strived to eliminate this limit by applying the pair comparison method, quantification of data and definition of criteria based on relevant empirical studies. It is necessary to point out that this in an expert analysis, rather than a user assessment; the outcomes therefore need to be interpreted from the point of view of experts and their knowledge of special didactic rules. The presented assessment would benefit from added qualitatively oriented content analysis of the selected visuals (such as an overview of positive and negative aspects of the selected visuals) and user assessment or testing (for example Behnke, 2017; Đukičin, Bibić, Lukić \& Dubovina, 2014; Peterson, 2016 and others). As part of the expert assessment of visuals, it is possible to further refine this methodology (e.g. through a questionnaire survey among experts on visual quality criteria) or to apply this methodology to other geography textbooks or other chapters.

Visuals in geography textbooks have the potential to make the learning process more effective; however, their educational potential is not used to the full extent in certain cases. This is especially due to the selection of unsuitable means of expression, professional errors in visuals and unsuitable position of visuals in the structure of textbooks. Visuals should be designed with an emphasis on adequacy with regard to terminology and the visualised phenomena. Furthermore, authors should pay attention to the use of illustrative means of expression. Attention should also be paid to suitable 
integration of visuals in textbooks (for example the semantic and distance relationship to the text, suitability of title). This can be achieved by involving experts in cartography, geographical education, didactics or psychology in the creation of textbooks and their close cooperation with the authors, editors and graphic artists of textbooks. This cooperation may be the key to improving the quality of the position of visuals in the textbook structure and thus making the learning process of students at elementary schools more effective.

\section{Acknowledgements}

This article was supported by SGS UJEP (project no. UJEP-SGS-2017-43-009-3 Visuals in geography textbooks and their impact on the occurrence of misconceptions) and GA ČR (project no. 16-01003S Visual geographical information and its role in geographical education).

\section{References}

Ainsworth, S. (2006). DeFT: A conceptual framework for considering learning with multiple representations. Learning and Instruction, 16(2), 183-198.

Behnke, Y. (2017). Mapping the reading of graphic visualisations in geography textbooks. In: N. Pyyry, L. Taino, K. Juuti, R. Vasquez \& M. Paananen. Changing Subjects, Changing Pedagogies: Diversities in School and Education (pp. 68-89). Helsinki: Oy Nord Print Ab.

Benson, P. (1997) Problems in picturing text: A study of visual/verbal problem solving. Technical Communication Quarterly, 6(2), 141-160.

Bláha, J. D. (2006). Paradox inovace v kartografii z pohledu estetiky. Kartografické listy, 14, 515.

Bláha, J. D. (2010). Various ways of assessment of cartographic works. In G. Gartner \& F. Ortag (Eds.), Cartography in Central and Eastern Europe (pp. 211-231). New York: Springer.

Bresciani, S., \& Eppler, M. J. (2015). The pitfalls of visual representations: A review and classification of common errors made while designing and interpreting visualizations. SAGE Open, 5(4), 1-14.

Borecký, D., Novák, S. \& Chalupa, P. (2013). Zeměpis. Brno: Nová škola.

Butcher, R. K. (2006). Learning from text with diagrams: Promoting mental model development and inference generation. Journal of Educational Psychology, 98(1), 182-197.

Canham, M., \& Hegarty, M. (2010). Effects of knowledge and display design on comprehension of complex graphics. Learning and Instruction, 20(2), 155-166.

Čechurová, M., Ježková, A. \& Borecký, D. (2016). Vlastivěda 4. Praha: SPN.

Chalupa, P. (2010). Naše vlast: místo, kde žijeme. Všeň: Alter.

Chalupa, P., Horník, S. \& Demek, J. (2015). Zeměpis 9. Praha: SPN.

Chytrý, V., \& Kroufek, R. (2017). Možnosti využití Likertovy škály - základní principy aplikace v pedagogickém výzkumu a demonstrace na př́kladu zjištování vztahu člověka k prírodě. Scientia in educatione, 8(1), 2-17. 
Cohen, L. (2007). Research methods in education. New York: Routlege.

Cromley, J. G., Perez, T. C., Fitzhugh, S. L., Newcombe, N. S., Wills, T. W., \&. Tanaka, J. C. (2013). Improving students' diagram comprehension with classroom instruction. The Journal of Experimental Education, 81(4), 511-537.

Dove, J. E., Everett, L. A., \& Preece, P. (1999). Exploring a hydrological concept through children's drawings. International Journal of Science Education, 21(5), 485-497.

Đukičin, S., Bibić, L., Lukić, T., \& Dubovina, Z. (2014). Analysis of the utilization of supplementary illustrations: An example of the selected teaching units from the fifth grade geography textbook (Republic of Serbia). Geographica Pannonica, 18(4), 29-95.

Fedotova, O., Latun, V., \& Okuneva, I. (2014). Visual image of the continent in Russian textbooks on geography (1825-2013). Procedia-Social and Behavioral Sciences, 14(5), 731-737.

Gregory, D. (Eds.). (2009). The Dictionary of human geography. Malden: Blackwell.

Hansen, T. I., \& Gissel, S. T. (2018). Quality of learning materials. IARTEM e-Journal, 9(1), $122-141$.

Hollman, V. (2014). Promoting visual literacy among undergraduate students in geography: Teaching a visualized Latin America. Journal of Geography in Higher Education, 38(1), 136-147.

Hroudová, S. \& Cimala, J. (2013). Vlastivěda 4. Brno: Nová škola - Duha.

Hublová, P. (2009). Člověk a jeho svět: pro 4. ročník základní školy. Brno: Didaktis.

Jackson, P. (2006). Thinking geographically. Geography, 91(3), 199-204.

Janko, T., \& Knecht, P. (2013). Visuals in geography textbooks: Categorization of types and assessment of their instructional qualities. Review of International Geographical Education Online, 3(1), 93-110.

Kastner, J., Holeček, M. \& Krajíček, L. (2016). Zeměpis naší vlasti. Praha: Nakladatelství ČGS.

Kim, S. Lim, S., \& Yang, I. (2016). An analysis of eye movement and cognitive load about the editorial design in elementary science textbook. Universal Journal of Educational Research, 4(3), 570-575.

Kirk, A. (2016). Data visualization. Los Angeles: Sage Publication.

Krippendorff, K. (2004). Content analysis: An introduction to its methodology. Thousand Oaks: Sage.

Kruskal, W. H., \& Wallis, A. (1952). Use of ranks in one-criterion variance analysis. Journal of the American Statistical Association, 47(260), 583-621.

Levin, J. R, Anglin, G. J., \& Carney, R. N. (1987). On empirically validating functions of picture in prose. In: Willows, D. \& Houghton, H. (eds.). The Psychology of Illustration. New York: Springer, pp. 51-86.

Lukinbeal, C. (2014) Geographic media literacy. Journal of Geography, 113(2), 41-46.

Mandelová, H. (2007). Moje vlast: o naší zemi, jejích obyvatelích a minulosti. Liberec: Dialog.

Mann, H. B., \& Whitney, D. R. (1947). On a test of whether one or two random variables is stochastically larger than the other. The Annals of Mathematical Statistics, 18(1), 50-60. 
Marada, M., Havlíček, T., Matějček, T., Hanus, M. \& Chromý, P. (2016). Zeměpis 8. Plzeň: Fraus.

Matušková, A. (2010). Místo, kde žijeme. Praha: Nakladatelství ČGS.

Matušková, A. \& Šmolíková, B. (2010). Místo, kde žijeme: vlastivěda pro 1. stupeň základní školy. Praha: Septima.

Mayer, R. E. (2009). Multimedia learning. NY: Cambridge University Press.

Mayer, R. E., \& Gallini, J. K. (1990). When is an illustration worth ten thousand words? Journal of Educational Psychology, 82(4), 715-726.

McTigue, E. M. (2009). Does multimedia learning theory extend to middle-school students? Contemporary Educational Psychology 34(1), 143-153.

McTigue, E. M., \& Flowers, A. C. (2011). Science visual literacy: Learners' perceptions and knowledge of diagrams. The Reading Teacher, 64(8), 578-589.

Melbo, I. R., \& Waterman, I. R. (1936). Pictures in geography textbooks. The Elementary School Journal, 36(5), 362-376.

Metallinos, N., Muffoletto, R., Petterson, R., Shaw, J., \& Takakuwa, Y. (1990). The use of verbo-visual information in textbooks - a cross-cultural experience. London: University of London.

Michaelidou, E. C., Nakos, B. P., \& Filippakopoulou, V. P. (2004). The ability of elementary school children to analyse general reference and thematic maps. Cartographica, 39(4), $65-88$.

Mikk, J. (2000). Textbook: research and writing. Frankfurt: Peter Lang.

Nielsen, J. (1994). Usability engineering. San Diego: Morgan Kaufmann.

Okeeffe, L. (2013). A framework for textbook analysis. International Review of Contemporary Learning Research, 2(1), 1-13.

Ozcelik, E., Karakus, T., Kursun, E., \& Cagiltay, K. (2009). An eye-tracking study of how color coding affects multimedia learning. Computers \& Education, 53(2), 445-453.

Paivio, A. (2014). Mind and its evolution: A dual coding theoretical approach. New York: Psychology Press.

Peeck, J. (1993). Increasing picture effects in learning from illustrated text. Learning and Instruction, 3(1), 227-238.

Pešková, K. (2012). Vizuální prostředky pro výuku reálií: výsledky analýzy učebnic němčiny. Pedagogická orientace, 22(2), 243-265.

Peterson, M. O. (2016). Schemes for integrating text and image in the science textbook: Effects on comprehension and situational interest. International Journal of Environmental \& Science Education, 11(6), 1365-1385.

Rose, G. (2008). Using photographs as illustrations in human geography. Journal of Geography in Higher Education, 32(1), 151-160.

Slough, S. W., McTigue, E. M., Kim, S., \& Jennings, S. K. (2010). Science textbooks use of graphical representation. Reading Psychology, 31(3), 301-325. 
Smolová, I. \& Szczyba, Z. (2008). Místo, kde žijeme: pro 4. a 5. ročník základní školy. Olomouc: Prodos.

Spousta, V. (2007). Vizualizace: gnostický a komunikační prostředek edukologických fenoménů. Brno: Masarykova Univerzita.

Sternberg, R. J. (2012). Cognitive psychology. Belmont: Wadsworth Cengage Learning.

Štiková V. \& Tabarková, J. (2016). Vlastivěda 4: poznáváme naši vlast. Brno: Nová škola.

Tang, G. M. (1994). Textbook illustrations: A cross-cultural study and its implications for teachers of language minority students. The Journal of Educational Issues of Language Minority Students, 13(2), 175-194.

Trahorsch, P., Bláha, J. D., \& Janko, T. (2018). Analýza výzkumů vizuálií v učebnicích na př́kladu učebnic s geografickým obsahem. Pedagogická orientace, 28(1), 111-134.

Verdi, E. P., \& Kulhavy, R. W. (2002). Learning with maps and texts: An overview. Educational Psychology Review, 14(1), 27-46.

Veriki, I. (2002). What is the value of graphical displays in learning? Educational Psychology Review, 14(3), 261-312.

Viceníková, M., Sakařová, L. \& Kamrla, J. (2016). Hravá vlastivěda 4. Praha: Taktik International.

Voženílek, V. \& Szczyrba, Z. (2015). Zeměpis 4: Česká republika. Olomouc: Prodos.

Wahla, A. (1983). Strukturni složky učebnic geografie. Praha: SPN.

Yasar, O., \& Seremet, M. (2007). A Comparative analysis regarding pictures included in secondary school geography textbooks taught in Turkey. International Research in Geographical and Environmental Education, 16(2), 157-187.

Zhang, H., \& Foskett, N. (2003). Changes in the subject matter of geography textbooks: 19071993. International Research in Geographical and Environmental Education, 12(4), 312329.

\section{Biographical Statements}

Petr TRAHORSCH is postgradual student at J. E. Purkyně in Ústí nad Labem. The focus of his research is geography education, especially textbooks analyses.

Jan D. BLÁHA is assistant professor at J. E. Purkyně in Ústí nad Labem. The focus of his research is analysis of cartographic works and usability of cartographic works.

Vlastimil CHYTRÝ is assistant professor at J. E. Purkyně in Ústí nad Labem. The focus of his research is quantitative analysis a mathematics education. 